\title{
PEMANFAATAN BOKASHI FESES SAPI TERHADAP PRODUKTIVITAS RATUN SORGUM VARIETAS KAWALI
}

\author{
Delty Indhira Wantania, A. Rumambi*, W. B. Kaunang
}

Fakultas Peternakan Universitas Sam Ratulangi Manado, 95115

\begin{abstract}
ABSTRAK
Penelitian ini bertujuan untuk mengetahui pengaruh pupuk bokashi feses sapi terhadap produktivitas ratun sorgum varietas kawali. Penelitian ini telah dilaksanakan di desa Wusa kecamatan Talawaan. Rancangan yang digunakan adalah Rancangan Acak Lengkap (RAL) yang terdiri dari 4 perlakuan dan 5 ulangan sehingga diperoleh 20 satuan percobaan. Perlakuan terdiri dari $\mathrm{P} 0=$ tanpa pemupukan, $\mathrm{P} 1=$ Pemupukan $4 \mathrm{~kg}, \mathrm{P} 2=$ Pemupukan $8 \mathrm{~kg}$, P3= Pemupukan $12 \mathrm{~kg}$. Variabel yang diukur adalah jumlah anakan, tinggi tanaman, dan berat malai. Hasil analisis statistik menunjukan bahwa perlakuan pemberian bokashi feses sapi 12 $\mathrm{kg} /$ petak memberikan pengaruh yang sangat nyata $(\mathrm{P}<0,01)$ terhadap jumlah anakan, tinggi tanaman, dan berat malai. Uji lanjut BNJ pada perlakuan jumlah anakan menunjukkan bahwa antara perlakuan P3, P0, P1, dan P2, berbeda sangat nyata $(\mathrm{P}<0,01)$. Pada perlakuan tinggi tanaman, uji lanjut BNJ menunjukkan antara perlakuan $\mathrm{P} 3, \mathrm{P} 0, \mathrm{P} 1$, dan $\mathrm{P} 2$ berbeda sangat nyata $(\mathrm{P}<0,01)$. Pada perlakuan berat malai uji lanjut BNJ menunjukkan bahwa antara perlakuan P3 dan $\mathrm{P} 0$, perlakuan $\mathrm{P} 3$ dan $\mathrm{P} 1$ berbeda sangat nyata $(\mathrm{P}<0,01)$, akan tetapi perlakuan $\mathrm{P} 3$ dan $\mathrm{P} 2$ menunjukkan perbedaan yang tidak nyata $(\mathrm{P}>0,05)$. Berdasarkan hasil penelitian yang telah dilaksanakan dapat disimpulkan bahwa pemberian pupuk bokashi feses sapi sampai dengan
\end{abstract}

*Korespondensi (Corresponding author) Email: agnitjerumambi@ymail.com
$12 \mathrm{~kg} /$ petak memberikan pengaruh terbaik terhadap jumlah tunas, tinggi tanaman, dan berat malai tanaman ratun sorgum.

Kata kunci: Bokashi, produktivitas, ratun, sorgum, kawali

\section{ABSTRACT \\ UTILIZATION OF BOKASHI FESES COW ON PRODUCTIVITY RATOON OF KAWALI SORGHUM VARIETY.}

This study aims to determine the effect of bokashi cow feces on the productivity of ratoon sorghum variety of kawali. This research was implemented in Wusa village at districts Talawaan. The design used was completely randomized design (CRD), which consists of 4 treatments and 5 replications to obtain 20 units of trial. The treatment consists of $\mathrm{P} 0=$ without fertilization, $\mathrm{P} 1=4 \mathrm{~kg}$ of fertilization, $\mathrm{P} 2=$ $8 \mathrm{~kg}$ of fertilization, $\mathrm{P} 3=12 \mathrm{~kg}$ of fertilization. The measured variables are number of tillers, plant height, and panicle weight. Result of the analysis showed that treatment with $12 \mathrm{~kg} /$ plot provides highly significant effect $(\mathrm{P}<0.01)$ of the number of tillers, plant height, and panicle weight compared with other treatments, ie 8 and 4 $\mathrm{kg} / \mathrm{plot}$. The HSD test indicated that treatment number of tillers showed that between treatment P3, P0, P1, and P2 showed highly significant. In the treatments of advanced test HSD indicated also that plant height between $\mathrm{P} 3, \mathrm{P} 0, \mathrm{P} 1$, and $\mathrm{P} 2$ showed highly significant. In the treatment of panicle weight of advanced test of HSD showed that between treatment $\mathrm{P} 3$ and $\mathrm{P} 0$, treatment of $\mathrm{P} 3$ and $\mathrm{P} 1$ is very different, but the treatment of $\mathrm{P} 3$ and $\mathrm{P} 2$ showed no 
significant difference. Based on this research it can be concluded that cattle feces bokashi as the organic fertilizer up to $12 \mathrm{~kg}$ produced the best effect on number of tillers, plant height, and panicle weight.

Keywords: Bokashi, productivity, ratoon, sorghum, kawali

\section{PENDAHULUAN}

Hijauan merupakan sumber pakan utama bagi ternak ruminansia, karena ketersediaan hijauan makanan ternak yang berkualitas sangat dibutuhkan untuk menunjang produktivitas ternak. Mengingat semakin berkurangnya lahan hijauan akibat besarnya pembangunan berupa pemukiman, Industri, maupun lahan pangan bagi manusia seperti pertanian dan perkebunan. Selain itu, pergantian musim juga sangat mempengaruhi fluktuasi hijaun pakan, dimana saat musim kemarau produksi hijauan sangat rendah.

\section{Sorgum (Sorghum bicolor} (L.)Moench) merupakan tanaman serealia yang potensial untuk dibudidayakan dan dikembangkan sebagai pakan ternak ruminansia, khususnya pada daerah-daerah marginal dan kering di Indonesia. Sorgum tumbuh tegak dan mempunyai daya adaptasi agroekologi yang luas, tahan terhadap kekeringan, produksi tinggi, membutuhkan input lebih sedikit serta lebih tahan terhadap hama dan penyakit dibanding tanaman pangan lain. Sorgum dapat dimanfaatkan sebagai hijauan pakan ternak. Potensi daun sorgum manis sekitar $14-16 \%$ dari bobot segar batang atau sekitar 3 ton daun segar/ ha dari total produksi 20 ton/ha. Pemberian daun sorgum pada ternak sapi tidak dapat diberikan secara langsung akan tetapi harus dilayukan dahulu sekitar 2-3 jam, sedangkan untuk nutrisi daun sorgum setara dengan rumput gajah dan pucuk tebu. Sorgum memiliki kandungan nutrisi yang tinggi, biji sorgum yaitu: protein 10,26\%; Serat kasar 2,72\%; Lemak 2,70\%; Ca 0,90\%; dan P 0,38\% dan kandungan nutrisi daun sorgum setara dengan rumput gajah dan pucuk tebu yang msing-masing : Protein kasar 7,82\%, 6\% dan 5,33\% Rumambi (2013) sehingga dapat dibudidayakan secara intensif sebagai sumber pakan hijauan bagi ternak ruminansia.

Salah satu teknik bubidaya yang perlu dipelajari dalam pengembangan sorgum adalah sistem ratun. Batang tanaman musim tanam pertama dipotong, dibiarkan tumbuh kembali dan dibudidayakan seperti sorgum yang ditanam dari benih. Beberapa keuntungan penerapan ratun pada tanaman sorgum yaitu penghematan benih karena pada musim tanam kedua tidak diperlukan benih lagi. Penghematan waktu karena tidak diperlukan lagi waktu untuk pengolahan 
tanah dan penanaman. Selain itu tanaman hasil ratun dapat dipanen lebih cepat, kebutuhan air lebih sedikit, serta biaya produksi lebih rendah karena penghematan dalam pengolahan tanah dan penggunaan benih. Pemotongan batang dimaksudkan untuk merangsang tumbuhnya tunas dan akar baru sehingga meningkatkan jumlah anakan dan jumlah daun tanaman (Mekbib, 2009; Puspitasari et al., 2012).

Kesuburan tanah sangat penting dalam upaya peningkatan produktivitas tanaman sorgum dengan penambahan unsur hara melalui fermentasi dengan pemberian EM4 (Effective Microorganisme-4). Pemupukan dapat menyediakan unsur hara yang diperlukan oleh tanaman dengan pemberian dosis yang tepat di harapkan dapat meningkatkan produktivitas tanaman sorgum. Bokashi merupakan salah satu jenis pupuk yang dapat menggantikan kehadiran pupuk kimia (anorganik) dalam menambah kesuburan tanah sekaligus memperbaiki kerusakan fisik, kimia, dan biologi tanah akibat pemakaian pupuk secara berlebihan. Bokashi merupakan hasil fermentasi bahan organik dari limbah pertanian (pupuk kandang, jerami, dan sekam serbuk gergaji dengan menggunakan EM4 (Gao et al., 2012; Atikah, 2013).

EM4 merupakan bakteri pengurai bahan organik yang memiliki keunggulan antara lainmemperbaiki kondisi tanah, menekan pertumbuhan mikroba yang menimbulkan penyakit dan memperbaiki efisiensi penggunaan bahan organik oleh tanaman. Kelebihan bahan organik bermanfaat dalam bidang peternakan, perikanan, dan pengelolahan limbah (Ruhukai, 2011). Selain itu, EM4 tidak meninggalkan efek residu yang negatif seperti bau dan panas.

Berdasarkan latar belakang di atas maka telah dilakukan penelitian tentang pemanfaatan bokashi feses sapi terhadap produktivitas ratun sorgum varietas kawali.

\section{MATERI DAN METODE PENELITIAN}

\section{Tempat dan Waktu Penelitian}

Penelitian ini telah dilakukan di Desa Wusa Kecamatan Talawaan Minut, Rancangan yang digunakan adalah Rancangan Acak Lengkap (RAL) (Steel dan Torrie, 1995) terdiri dari 4 perlakuan dan 5 ulangan sehingga diperoleh 20 satuan percobaan. Petak yang digunakan berukuran 2 × 3 meter, jumlah tanaman perpetak adalah 18 tanaman dengan jarak tanam 50 x $75 \mathrm{~cm}$. Perlakuan yang diberikan adalah :

$$
\begin{aligned}
& \text { P0 = Tanpa Pemupukan } \\
& \text { P1 = Pupuk Bokashi } 4 \mathrm{~kg} \\
& \text { P2 = Pupuk Bokashi } 8 \mathrm{~kg}
\end{aligned}
$$


P3 = Pupuk Bokashi $12 \mathrm{~kg}$

Peubah yang diukur dalam penelitian ini adalah :

- Jumlah anakan,

- Tinggi Tanaman $(\mathrm{cm})$ dan

- Berat Malai (g)

Bahan yang digunakan adalah: Benih sorgum variates kawali, feses sapi, EM4, gula putih, air sumur, serbuk gergaji, dedak halus dan tanah sebagai media tanam. Alat yang digunakan adalah: Cangkul, meter, timbangan, parang, kamera, bambu, paku, kertas HVS warna, tali, plastik, gunting, gelas ukur, kamera, sekop, ember, terpal, termometer dan alat tulis menulis.

\section{Pembuatan Bokashi Feses Sapi}

Persiapan bahan berupa larutan EM4 + gula + air dicampur merata. Selanjutnya penyiapan bahan-bahan pengisi seperti feses sapi, dedak halus, sekam padi, serbuk gergaji, semua bahan pengisi di campur secara bertahap. Bahan olahan ditutup menggunakan karung goni. Pengecekan suhu dilakukan setiap 5-6 jam, apabila terjadi peningkatan suhu pada bahan olahan perlu dilakukan pembongkaran dengan cara membolakbalikan bahan tersebut agar terjadi penurunan suhu kemudian ditutup kembali. Bokashi dapat digunakan apabila telah memiliki ciri berwarna coklat kehitaman, tekstur lembut, gembur, tidak panas, dan tidak berbau busuk.

Penelitian ini merupakan penelitian lanjutan, jadi pemupukan dilakukan pada penanaman sorgum yang pertama, untuk mengetahui apakah pemupukan yang dilakukan dengan bokashi feses sapi masih memberikan pengaruh terhadap produktivitas anakan sorgum.

\section{Persiapan lahan meliputi:}

Pembersihan tanah dengan cara pembajakkan atau pembongkaran tanah kemudian dilakukan penyisiran agar bersih dari sisa-sisa tanaman dan rumput liar dilanjutkan dengan pembuatan petak sebanyak 20 petak dengan ukuran 2 x 3 meter, jarak antar petak adalah $50 \times 75 \mathrm{~cm}$. Tanah yang telah dibuat petak-petak tadi dibiarkan selama 1 minggu untuk membiarkan kesempatan bagi rumput liar tumbuh kemudian dicangkul kembali. Dilanjutkan dengan pemberian pupuk sesuai perlakuan pada tiap-tiap petak. Hasil analisis tanah yang digunakan dalam penelitian ini berdasarkan Laboratorium Balai Penelitian Tanaman Palma Mapanget (Manado) yaitu Kadar Air 4,13\%, $\mathrm{pH} \mathrm{H}_{2} \mathrm{O}$ 6,52, pH KCl 1M 5,25, Kadar N 0,21\%, P Bray 10,4 ppm, C-Organik 1,78\%.

\section{Penanaman}

Penanaman dilakukan dengan cara tunggal, dimana setiap lubang ditanami 23 butir, setelah tanaman berumur 1 minggu 
dilakukan penjarangan dengan meninggalkan satu tanaman per lubang. Setiap petak ditanami 18 tanaman sehingga keseluruhan petak berjumlah 360 tanaman.

Pemeliharaan tanaman meliputi penyiangan dilakukan apabila muncul tanaman pengganggu dalam petak percobaan. Penyemprotan dilakukan menggunakan furadan dan sefin pada tanaman yang terserang hama.

\section{Pengambilan data}

Pengambilan data dilakukan 2 minggu setelah pemotongan batang tanaman utama terhadap jumlah anakan, tinggi tanaman, dan berat malai pada umur 90 hari.

\section{HASIL DAN PEMBAHASAN}

\section{Jumlah Anakan}

Pengaruh perlakuan terhadap jumlah tunas dapat dilihat pada Tabel 1. Rataan jumlah anakan tertinggi terdapat pada perlakuan P3 $(7,02)$ diikuti oleh P2 $(5,98)$, P1 $(4,89)$ dan yang terendah pada perlakuan P0 $(3,47)$. Hasil analisis sidik ragam menunjukkan bahwa perlakuan pemupukkan memberikan pengaruh yang sangat nyata $(\mathrm{P}<0,01)$ terhadap jumlah anakan. Uji lanjut BNJ memperlihatkan bahwa perlakuan P3 menunjukkan perbedaan yang lebih tinggi dibandingkan dengan P0 (tanpa pemupukan), P1, dan P2 memberikan pengaruh yang sangat nyata $(\mathrm{P}<0,01)$ terhadap jumlah anakan. Semakin tinggi level pupuk semakin meningkat jumlah anakan tanaman sorgum, hal ini di karenakan bokashi yang ditambahkan ke dalam tanah dapat mensuplai hara melalui dekomposisi bahan organik, sehingga meningkatkan ketersediaan unsur-unsur hara tersebut dalam tanah (Syam, 2003; Nguyen dan Shindo, 2011). Diketahui bahwa bokashi feses sapi mengandung unsur hara makro dan mikro yang sangat dibutuhkan oleh tanaman sorgum. Unsur hara $\mathrm{N}$ berfungsi sebagai perangsang pertumbuhan tanaman secara keseluruhan, khususnya batang, cabang dan daun (Hakim et al., 1986). Selanjutnya dikatakan bahwa unsur $\mathrm{P}$ berfungsi sebagai memacu pertumbuhan akar dan pembentukan sistem perakaran yang baik sehingga tanaman dapat menyerap unsur hara lebih banyak dan pertumbuhan tanaman menjadi sehat dan kuat. Sedangkan unsur K berfungsi untuk mengaktifkan enzim-enzim yang mempercepat pertumbuhan jaringan meristimatik (Setyamidjaya, 1996). Lanjut dikatakan juga bahwa unsur $\mathrm{K}$ dapat diserap tanaman mengakibatkan pertumbuhan jaringan meristimatik juga akan lebih baik dan pertumbuhan tunas yang menentukan saat tumbuh stek juga akan lebih cepat. Penelitian Riyani et al, (2013) pada tanaman padi yang 
Tabel 1. Rataan Pengaruh Perlakuan Pupuk Bokashi Feses Sapi Terhadap Jumlah Anakan, Tinggi Tanaman Dan Berat Malai.

\begin{tabular}{|c|c|c|c|c|c|c|}
\hline \multirow{2}{*}{ Variabel } & \multicolumn{4}{|c|}{ Perlakuan } & \multirow{2}{*}{ SEM } & \multirow{2}{*}{ Signifikan } \\
\hline & $\mathrm{P} 0$ & $\mathrm{P} 1$ & $\mathrm{P} 2$ & P3 & & \\
\hline $\begin{array}{l}\text { Jumlah } \\
\text { Anakan } \\
\text { Tinggi }\end{array}$ & $3,47^{\mathrm{a}} \pm 0,22$ & $4,89^{\mathrm{b}} \pm 0,18$ & $5,98^{\mathrm{c}} \pm 0,07$ & $7,02^{\mathrm{d}} \pm 0,14$ & 0,311 & Sig \\
\hline $\begin{array}{l}\text { Tanaman } \\
\text { Berat }\end{array}$ & $147^{\mathrm{a}} \pm 2,16$ & $162,6^{\mathrm{b}} \pm 7,87$ & $176^{\mathrm{b}} \pm 3.47$ & $196,2^{c} \pm 2,57$ & 4,655 & Sig \\
\hline Malai & $286^{\mathrm{a}} \pm 18,01$ & $309,4^{\mathrm{ab}} \pm 19,76$ & $345,6^{\mathrm{bc}} \pm 13,96$ & $387,8^{c} \pm 7,57$ & 11,352 & Sig \\
\hline
\end{tabular}

menggunakan pupuk kotoran sapi lebih tinggi yaitu 8,55 tunas.

\section{Tinggi Tanaman}

Pengaruh perlakuan terhadap tinggi tanaman dapat dilihat pada Tabel 1. Nilai rataan perlakuan P3 memberikan tinggi tanaman tertinggi yaitu $(196,2 \mathrm{~cm})$ diikuti dengan P2 $(176 \mathrm{~cm}), \mathrm{P} 1(162,6 \mathrm{~cm})$ dan yang terendah P0 (147 cm). Uji lanjut BNJ menunjukan bahwa perlakuan P3 berbeda sangat nyata $(\mathrm{P}<0,01)$ lebih tinggi dibandingkan perlakuan P0, P1, dan P2 terhadap tinggi tanaman sorgum. Hal ini disebabkan karena adanya sumbangan bahan organik tanah berasal dari bokashi yang merupakan pupuk organik yang baik. Sarief (1986) mengatakan bahwa tersedianya unsur hara yang cukup saat saat pertumbuhan maka proses fotosintesis akan lebih aktif, sehingga pemanjangan, pembelahan dan diferensiasi sel akan lebih baik. Jadi semakin banyak unsur hara yang dapat diserap oleh tanaman sorgum maka proses proses fotosintesis akan lebih aktif sehingga akan mempercepat pertumbuhan tinggi tanaman. Hasil penelitian ini lebih tinggi dari penelitian Imban et al. (2017) yang menghasilkan tinggi tanaman 168,20 $\mathrm{cm}$ menggunakan bokashi feses sapi. Lain halnya dengan penelitian Rumambi (2012) menggunakan pupuk hayati fungi mikoriza arbuscula (FMA) dan aplikasi fosfat alam menghasilkan tinggi tanaman yang lebih tinggi yaitu $247,86 \mathrm{~cm}$.

\section{Berat Malai}

Pengaruh perlakuan terhadap berat malai dapat dilihat pada Tabel 1. Nilai rataan perlakuan P3 memberikan Berat Malai tertinggi yaitu (387,8 gram) diikuti dengan P2 (345,6 gram), P1 (309,4 gram) dan yang terendah P0 (286 gram). Hasil analisis sidik ragam menunjukkan bahwa perlakuan memberikan pengaruh yang berbeda sangat nyata $(\mathrm{P}<0,01)$ terhadap 
berat malai. Uji lanjut BNJ menunjukkan bahwa perlakuan P3 berbeda sangat nyata $(\mathrm{P}<0,01)$ lebih tinggi dibandingkan $\mathrm{P} 0$ dan P1) sedangkan P3 dan P2 memberikan pengaruh yang berbeda tidak nyata $(\mathrm{P}>0,05)$ terhadap berat malai. Semakin tinggi level pupuk kandang maka makin tinggi berat malai, dikarenakan adanya pemberian pupuk bokashi feses sapi yang dapat memperbaiki sifat fisik, kimia dan biologi tanah sehingga tanah menjadi lebih subur. Hal ini karena unsur hara cukup yang berasal dari dalam tanah dan dari pupuk bokashi yang diberikan berpengaruh pada pembentukan biji untuk bobot malai. Menurut Hakim (1986) penambahan pupuk kandang sebagai salah satu bahan organik dapat mempertinggi humus dan mendorong kehidupan jasad renik tanah yang akan membantu proses dekomposisi bahan organik. Hasil penelitian yang diperoleh ini lebih tinggi dari hasil penelitian Tacoh et al. (2017) yang menghasilkan berat malai 377 g dengan menggunakan bokashi feses sapi. Hal ini diduga makin tinggi dosis bokashi makin banyak unsur hara yang diserap sehingga memberikan sumbangan hara yang besar dalam bobot biji.

\section{KESIMPULAN}

Berdasarkan hasil penelitian yang telah dilaksanakan dapat disimpulkan bahwa pemberian pupuk bokashi feses sapi sampai dengan $12 \mathrm{~kg} /$ petak memberikan pengaruh terbaik terhadap jumlah tunas, tinggi tanaman, dan berat malai tanaman ratun sorgum.

\section{DAFTAR PUSTAKA}

Atikah, T. A. 2013. Pertumbuhan dan hasil tanaman terung ungu varietas yumi F1 dengan pemberian berbagai bahan organik dan lama inkubasi pada tanah berpasir. Anterior Jurnal 12(2):6-12

Gao, M., J. Li, and X. Zhang. 2012. Responses of soil fauna structure and leaf litter decomposition to effective microorganism treatments in Dahinggan Mountains, China. Chinese Geographical Science. Journal Vol 22(6): 647-658.

Hakim, N., M. Y. Nyakpa, A. M. Lubis, S. G. Nugroho, M. A. Diha, Go Ban Hong, dan H. Bailey. 1986. DasarDasar Ilmu Tanah. Penerbit Universitas Lampung.

Imban, S.S., A. Rumambi, S. S. Malalantang. 2017. Pengaruh pemanfaatan bokashi feses sapi terhadap pertumbuhan sorgum varietas kawali. Jurnal Zootek. Vol. 37(1): $80-87$

Mekbib, F. 2009. Farmers breeding of sorghum in the centre of diversity, Ethiopia: socio-ecotype differentiation, varietal mixture and selection efficiency. Journal Maydica. 54:25-37.

Nguyen, T.H., dan H. Shindo. 2011. Effects of different levels of compost application on amounts and 
distribution of organic nitrogen forms in soil particle size fractions subjected mainly to double cropping. Journal Agricultural Sciences 2(3): 213-219.

Puspitasari, G., D. Kastono, S. Waluyo. 2012. Pertumbuhan dan hasil sorgum manis (Sorghum bicolor (L.) Moench) tanam baru dan ratoon pada jarak tanam berbeda. Jurnal Vegetalika. 1(4):18-29.

Riyani, R., Radian, dan Setia Budi. 2013. Pengaruh berbagai pupuk organik terhadap pertumbuhan dan hasil padi di lahan pasang surut. Fakultas Pertanian. Universitas Tanjung Pura. Jurnal sains mahasiswa pertanian Vol 2 (2):1-11

Ruhukai, N. L. 2011. Pengaruh penggunaan EM4 yang dikulturkan pada bokashi dan pupuk anorganik terhadap produksi tanaman kacang tanah (Arachis hypogaeaL.) di Kampung Wanggar Kabupaten Nabire. Jurnal Agroforestri VI(2):114-120.

Rumambi, A. 2012. Penyediaan pakan berkelanjutan melalui inokulasi fungi mikoriza arbuscula dan aplikasi fosfat alam pada Arachis Pintoi dalam tumpang sari dengan jagung atau sorgum. Disertasi. Sekolah Pascasarjana Institut Pertanian Bogor.

Rumambi, A. 2013. Karakteristik pertumbuhan sorgum dengan pemupukan urea berbeda sebagai sumber nitrogen. Jurnal Agrosistem Vol 10 (1): 1-12.

Sarief, E. S. 1986. Kesuburan dan Pemupukan Tanah Pertanian. Pustaka Buana. Bandung.
Setyamidjaja, D. 1996. Pupuk dan Pemupukan. Sinaplex Djakarta. 122 hal.

Steel, G. D. dan J. H. Torrie. 1991. Prinsip dan Prosedur Statistika Suatu

Pendekatan Biometrik. Edisi kedua. Gramedia Pustaka Utama. Jakarta.

Syam, A. 2003. Efektivitas pupuk organik dan anorganik terhadap produktivitas padi dilahan sawah. Jurnal Agrivigor 3(3):232-244.

Tacoh, E., A. Rumambi, W. B. Kaunang 2017. Pengaruh pemanfaatan pupuk bokashi feses sapi terhadap produksi sorgum varietas kawali. Jurnal Zootek. Vol. 37 (1): 88 - 95 